\title{
Molecular phylogenetic analysis of Cysticercus ovis from Egypt based on MT-CO1 gene sequences
}

\author{
Análise filogenética molecular de Cysticercus ovis do Egito com base nas sequências do gene MT-COI \\ Amer Ragheb Abdelaziz ; Reda Elbastawisy Khalafalla2* (D); Amal Abbas Abdelrahman Hassan³; \\ Ehab Kotb Elmahallawy ${ }^{4}$; Abdulaziz Mohammed Almuzaini ${ }^{5}$ \\ ${ }^{1}$ Department of Parasitology, Faculty of Veterinary Medicine, Sohag University, Sohag, Egypt \\ ${ }^{2}$ Department of Parasitology, Faculty of Veterinary Medicine, Kafrelsheikh University, Kafr El-Sheikh, Egypt \\ ${ }^{3}$ Department of Biology, Faculty of Science, Damanhur University, Damanhur, Egypt \\ ${ }^{4}$ Department of Zoonotic Diseases, Faculty of Veterinary Medicine, Sohag University, Sohag, Egypt \\ ${ }^{5}$ Department of Veterinary Medicine, College of Agriculture and Veterinary Medicine, Qassim University, Buraydah, Saudi Arabia
}

Received December 16, 2018

Accepted March 25, 2019

\begin{abstract}
Cysticercus ovis or sheep measles is the larval stage of Taenia ovis, which is the intestinal tapeworm of dogs. It is found in the cardiac and skeletal muscles of sheep and can be the cause of partial or total condemnation of carcasses at abattoirs. The aim of the current work was to determine the prevalence of $C$. ovis among sheep in Upper Egypt and to present the molecular and phylogenetic analysis of this using the amplified Mitochondrial Cytochrome Oxidase subunit 1 (MT-CO1) gene. A total of 1885 sheep slaughtered at local abattoirs of 4 different governorates of Upper Egypt (Asuit, Sohag, Qena and Aswan) were carefully examined for $C$. ovis. The overall prevalence of infection was $2.02 \%$. The highest rate of infection was observed in adult animals over 4 years of age (44.73\%). There was no significant effect of animal sex on infection rates. The phylogenic analysis of $C$. ovis Egyptian isolates showed very close similarity to the New Zealand isolate (AB731675). This is the first report showing the genetic analysis of C. ovis in Egypt, which provides a very powerful tool for taxonomy and definitive diagnosis of $C$. ovis, which could be helpful for preventive and control programs.
\end{abstract}

Keywords: Cysticercus ovis, sheep, prevalence, molecular, phylogeny.

\section{Resumo}

Cysticercus ovis "sheep measles" é o estágio larval da Taenia ovis, encontrada nos músculos de carneiros, causado pela ingestão de ovos de Taenia ovis, parasita de cáes. O objetivo do presente trabalho foi determinar a prevalência de $C$. ovis entre ovinos no Alto Egito e apresentar as análises moleculares e filogenéticas, utilizando o gene da subunidade mitocondrial citocromo-oxidase amplificada 1 (MT-CO1). Um total de 1885 ovinos abatidos em matadouros locais de 4 províncias diferentes do Alto Egito (Asuit, Sohag, Qena e Aswan) foram cuidadosamente examinados para C. ovis. A prevalência geral de infecção foi de 2,02\%. A maior taxa de infecção foi observada em animais adultos com mais de 4 anos de idade (44,73\%). Não houve efeito significativo do sexo nas taxas de infecção. A análise filogenética de isolados egípcios de C. ovis mostrou uma similaridade muito próxima ao isolado da Nova Zelândia (AB731675). Este é o primeiro relato mostrando a análise genética de $C$. ovis no Egito, fornecendo uma ferramenta para taxonomia e diagnóstico definitivo de C. ovis, podendo ser útil para programas preventivo e de controle.

Palavras-chave: Cysticercus ovis, ovinos, prevalência, molecular, filogenia.

\section{Introduction}

In Egypt, the sheep population is estimated at 5.5 million animals (OIE, 2017; SULTAN et al., 2016), raised mainly in either small numbers kept in the household by farmers or in village flocks managed by shepherds (AIDAROS, 2005).

${ }^{*}$ Corresponding author: Reda Elbastawisy Khalafalla. Department of Parasitology, Faculty of Veterinary Medicine, Kafrelsheikh University, P.O. Box 33516, Kafr El-Sheikh, Egypt. e-mail: redabast@hotmail.de
Sheep and goats are the intermediate host for several canine tapeworm species, including Taenia ovis. In sheep, the larval stages of this cestode, $C$. ovis, cause cystic lesions in skeletal and heart muscle (SOULSBY; MÖNNIG, 1982).

The habitat of the adult cestode worm T. ovis is the intestine of dogs, foxes and wolves. Sheep get the infection through eggs on contaminated pastures or feeding on contaminated garbage 
(DEWOLF et al., 2014). The parasitic cycle is completed after the definitive host eats viable $C$. ovis cysts.

Usually, the specific identification of taeniids has been centered on morphological measures, usually with regards to ecological and biological aspects like host specificity (ABULADZE \& SKRJABIN, 1964).

The development of molecular genetic techniques has provided advanced tools for the identification of taeniid species and for investigating relationships among them. In particular, mitochondrial DNA sequencing has been successfully used for the identification and genetic characterization of these parasites (BOWLES \& MCMANUS, 1994).

Based on morphology, several studies have been conducted in Egypt to identify C. ovis of sheep (DYAB et al., 2017; FAHMI, 2014; OMAR et al., 2016; SULTAN et al., 2010), and very few of these studies focused on the molecular and phylogenetic characterization of C. ovis in Upper Egypt.

Parasitic infections have a great economic impact on animal production and causes losses including the retardation of growth, emaciation, and low production of milk, meat and wool. Furthermore, Cysticercus ovis in particular is causing economic losses due to partial or total condemnation of the carcass (PERRY \& RANDOLPH, 1999; ZHENG, 2016). Therefore the aim of the present study was to determine the prevalence of $C$. ovis among slaughtered sheep in Upper Egypt, and to apply the molecular phylogenetic analysis of $C$. ovis through the use of Mitochondrial Cytochrome Oxidase subunit I (MT-CO1) gene sequencing.

\section{Materials and Methods}

\section{Ethical considerations}

This study followed the institutional ethical and animal care guidelines approved by supreme council of Egyptian universities, Egypt. All procedures were explained prior to sampling to abattoir authorities, veterinarians, and owners. The sheep from which C. ovis were collected in selected provinces in Upper Egypt were part of the normal work of the abattoir.

\section{Study area}

The samples were collected from local abattoirs of the Upper Egypt governorates Assiut, Sohag, Qena and Aswan over the period from January to December 2017 (Figure 1).

\section{Sample collection and laboratory examination}

A total of 1885 samples were included in the study. Samples were collected and labeled with location, age, sex and site of infection.

Slaughtered sheep were subjected to routine meat inspection. The heart, diaphragm, tongue and major skeletal muscles were investigated for the presence of any $C$. ovis cysts by visual inspection, incisions and palpation. The muscles infected with $C$. ovis cyst were transferred to the laboratory of the Parasitology department, Faculty of Veterinary Medicine, Sohag University.

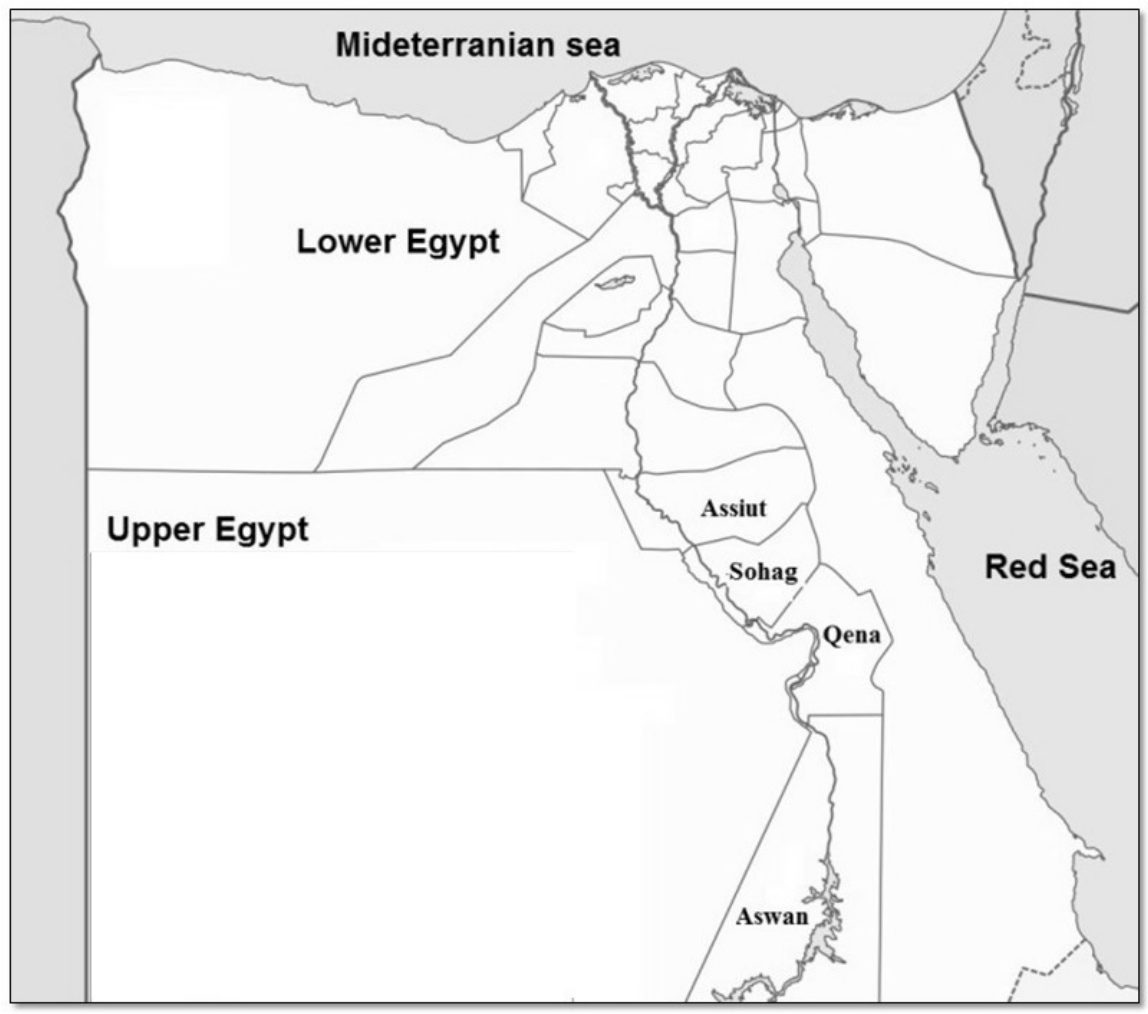

Figure 1. Map of Egypt showing the prevalence of infection of Cysticercus ovis among sheep in governorates of Upper Egypt. 
Samples were fixed in $10 \%$ buffered formalin, stained with alum-carmine and mounted on glass slides for morphological identification (KAUFMANN, 2013; SOULSBY \& MÖNNIG, 1982) while other samples were fixed in $70 \%$ ethanol for molecular identification.

\section{Molecular characterization}

\section{DNA extraction}

Approximately 25 C. ovis cysts from the infected muscles were pooled and washed in normal physiological saline. DNA extraction was performed once from the 25-pooled cysts using the Qiagen Tissue Kit (Qiagen, Germany) according to the manufacturer's protocol.

PCR, and sequencing of the mitochondrial MT-CO1 gene

The MT-CO1 gene was amplified by PCR using the following primer pairs: CO1-F 5'-ATGAATATTAAAACTTTATTAAGTTGGA-3' and CO1-R 5'-TTAAACTAAAAAACCACGGGCA-3', and this was performed with minor modifications according to methods previously described (Shi et al., 2016). PCR was done with the following conditions: $94^{\circ} \mathrm{C}$ for $5 \mathrm{~min}$, then followed by 30 cycles of $94^{\circ} \mathrm{C}$ for $1 \mathrm{~min}, 50^{\circ} \mathrm{C}$ for $35 \mathrm{~s}, 72^{\circ} \mathrm{C}$ for $2 \mathrm{~min}$ and a final extension at $72{ }^{\circ} \mathrm{C}$ for $10 \mathrm{~min}$.

PCR products were observed on a $1.0 \%(\mathrm{w} / \mathrm{v})$ ethidium bromide stained agarose gel and visualized and photographed on a UV transilluminator. PCR products were directly purified and sequenced using the ABI 3370 DNA sequencer at the Molecular Biology Unit (Animal Health Research Institute, El-Dokky, Egypt) applying a primer walking strategy (JIA et al., 2010).

\section{Assembling of nucleotide sequences and phylogenic analysis}

The obtained MT-CO1 sequences of $C$. ovis were edited in MEGA6 (TAMURA et al., 2013) and Clustal W 12.1 V software, and were also aligned with reference sequences available using BLAST algorithms and databases from the National Center for Biotechnology (NCBI).

The phylogram was constructed using the neighbor-joining method analysis of coding genes in the mitochondrial genome of $T$. ovis based on comparison and alignment with reference sequences of other species in Taeniidae (LAVIKAINEN et al., 2008; SHI et al., 2016) (Figure 2), and the tree was rooted with C. pisiformis (GU569096.1) using Kimura's two parameter model. The phylogram is drawn to scale, with branch lengths (next to the

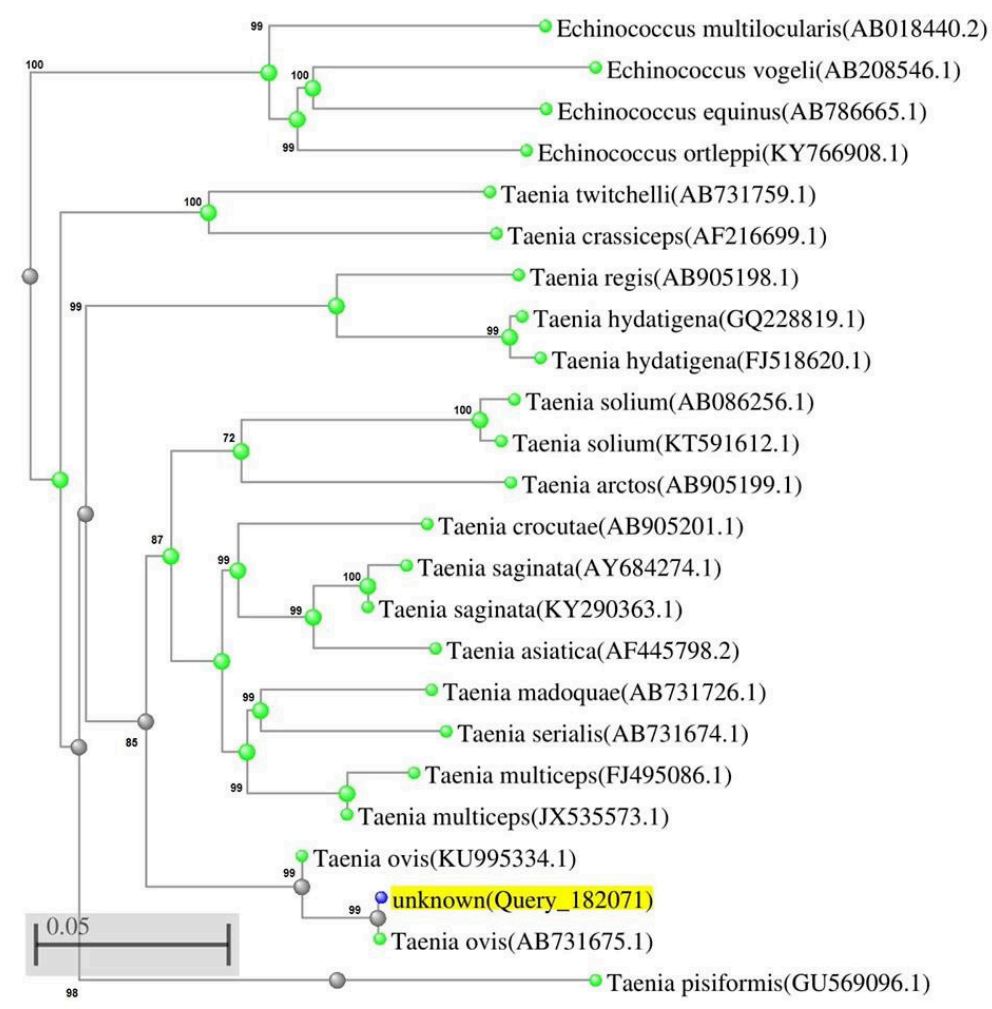

Figure 2. Phylogenetic tree and evolutionary relationship of Taenia (Cysticercus) ovis Egyptian isolate (Unknown (Query_182071) based on the MT-CO1 gene locus using the Clustal program for pair-wise and multiple sequence alignment; the tree was constructed by the neighbor-joining analysis (NJ) with MEGA6 software using Echinococcus multilocularis as out group, with genetic distance of 0.05 , it was closely similar to T. ovis New Zealand isolate with Accession no. (AB731675.1) and (KU995334.1) (TAMURA et al., 2013). 
branches) in the same units as those of the evolutionary genetic distances $(0.05 \%)$ (TAMURA et al., 2013). The double bootstrap method is used in this study to assess the reliability of the statistical analysis and probability of branches distances.

\section{Statistical analysis}

The statistical analysis was conducted using the statistical package of Excel in Microsoft Office to calculate prevalence, and SPSS statistics 20 (2002) IBM software to calculate standard error, $P$-value, odds ratio (OR) and confidence interval at $99 \%$ (99\% CI) to detect risk factors associated with the infection. A statistically significant association between variables was selected if the calculated $P$-value was less than $0.001(P<0.001)$.

\section{Results}

\section{Prevalence and associated risk factors of C. ovis}

The overall prevalence of $C$. ovis infection among 1885 slaughtered sheep in the Assiut, Sohag, Qena and Aswan governorates of Upper Egypt was 2.02\% (99\% CI: 0.860-1.069). The highest rate of infection with C. ovis was $2.7 \%$ observed in Qena province, while the lowest rate was $1.49 \%$ observed in Aswan province (Table 1, Figure 1).

Statistically, there was no association between the infection rate and the locality of infection and no significant differences between them with a $P$-value of 0.318 (OR: $0.959,99 \%$ CI: $0.860-1.069$ ).

As displayed in Table 1, the highest infection rate, 44.73\%, was among sheep with ages of 4 years and above and the age is not a potential risk factor for the infection as the $P$-value was 0.045 (OR: 1.337, 99\% CI: 0.260-0.437).

The results (Table 1, Figure 3) show that C. ovis appeared as whitish small cyst ranged from $1-1.5 \mathrm{~cm}$ diameter and was recovered from cardiac, diaphragmatic, costal and abdominal muscles. Microscopically, it was stained red by Alum-carmine stain and seen as long invaginated protoscolex with a rostellum armed with Taeniidae hooks and four rounded suckers (Figure 4).

Regarding to the site of the infection, the cardiac muscles showed the highest infection rate $(34.21 \%)$, with a $P$-value less than 0.001 , showing a highly significant difference compared to other tissues (OR: 1.370, 99\% CI: 1.066-1.761; $P<0.001$ ) and a strong association between cardiac muscle and $C$. ovis infection in sheep.

In addition, the infection rate among males (52.63\%) was higher than in females (47.36\%), as shown in Table 1, without significant difference, where the $P$-value was 0.550 (OR: 0.917 , 99\% CI: 0.631-1.333). Statistically, there was no association between the animal's sex and the infection rate.

\section{Sequence analysis and phylogeny of C. ovis}

The amplified DNA fragment size of the MT-CO1 gene was nearly $437 \mathrm{bp}$. The pair wise comparison illustrates the low distance between the sequences from selected T. ovis compared with reference sequences from GenBank.

The Egyptian isolate of the current study is highly similar to other T. ovis isolates, as it shared 99\% identity with the MT-CO1 gene of the T. ovis New Zealand isolate in GenBank AB731675.1 (NAKAO et al., 2013), of China in GenBank KU995334.1 (SHI et al., 2016) and other reference sequences (Figure 2), while

Table 1. Prevalence of Cysticercus ovis infection and different associated risk factors in examined slaughtered animals among Assiut, Sohag, Qena and Aswan the provinces of Upper Egypt.

\begin{tabular}{|c|c|c|c|c|c|c|c|c|c|}
\hline \multirow{2}{*}{\multicolumn{2}{|c|}{ Risk factor }} & \multirow{3}{*}{$\begin{array}{c}\text { Exam } \\
418\end{array}$} & \multirow{3}{*}{$\begin{array}{c}\text { Inf. } \\
11\end{array}$} & \multirow{3}{*}{$\begin{array}{c}\% \\
2.63\end{array}$} & \multirow{3}{*}{$\begin{array}{c}\text { S.E. } \\
0.042\end{array}$} & \multirow{3}{*}{$\begin{array}{c}\text { P-value } \\
0.318\end{array}$} & \multirow{3}{*}{$\begin{array}{c}\begin{array}{c}\text { O. R. } \\
\text { Lower }\end{array} \\
0.959\end{array}$} & \multicolumn{2}{|c|}{ 99\% C.I. } \\
\hline & & & & & & & & \multirow{2}{*}{$\begin{array}{c}\text { Upper } \\
\mathbf{0 . 8 6 0}\end{array}$} & \multirow[b]{2}{*}{1.069} \\
\hline locality & Assiut & & & & & & & & \\
\hline & Sohag & 836 & 14 & 1.67 & & & & & \\
\hline & Qena & 296 & 8 & 2.7 & & & & & \\
\hline & Aswan & 335 & 5 & 1.49 & & & & & \\
\hline & Total & 1885 & 38 & 2.02 & & & & & \\
\hline \multirow[t]{4}{*}{ Age } & $1-2 y$. & 383 & 7 & 1.82 & 0.101 & 0.0446 & 1.337 & 1.260 & 1.437 \\
\hline & $2-4 y$ & 846 & 14 & 1.65 & & & & & \\
\hline & Over4y. & 656 & 17 & 2.59 & & & & & \\
\hline & Total & 1885 & 38 & 2.02 & & & & & \\
\hline \multirow{5}{*}{$\begin{array}{c}\text { Site of } \\
\text { infection }\end{array}$} & Cardiac & 1885 & 13 & 0.69 & 0.097 & $0.001^{*}$ & 1.370 & 1.066 & 1.761 \\
\hline & Abdominal & 1885 & 8 & 0.42 & & & & & \\
\hline & Costal & 1885 & 6 & 0.32 & & & & & \\
\hline & Diaphragm & 1885 & 11 & 0.85 & & & & & \\
\hline & Total & 1885 & 38 & 2.02 & & & & & \\
\hline \multirow[t]{3}{*}{ Sex } & Male & 998 & 20 & 52.63 & 0.145 & 0.550 & 0.917 & 0.631 & 1.333 \\
\hline & Female & 887 & 18 & 47.36 & & & & & \\
\hline & Total & 1885 & 38 & 2.02 & & & & & \\
\hline
\end{tabular}

99\% C.I: Confidence Interval at 99\%; S.E: Standard Error; O.R: Odds Ratio; ${ }^{*}($ significant at P $\leq 0.001)$. 

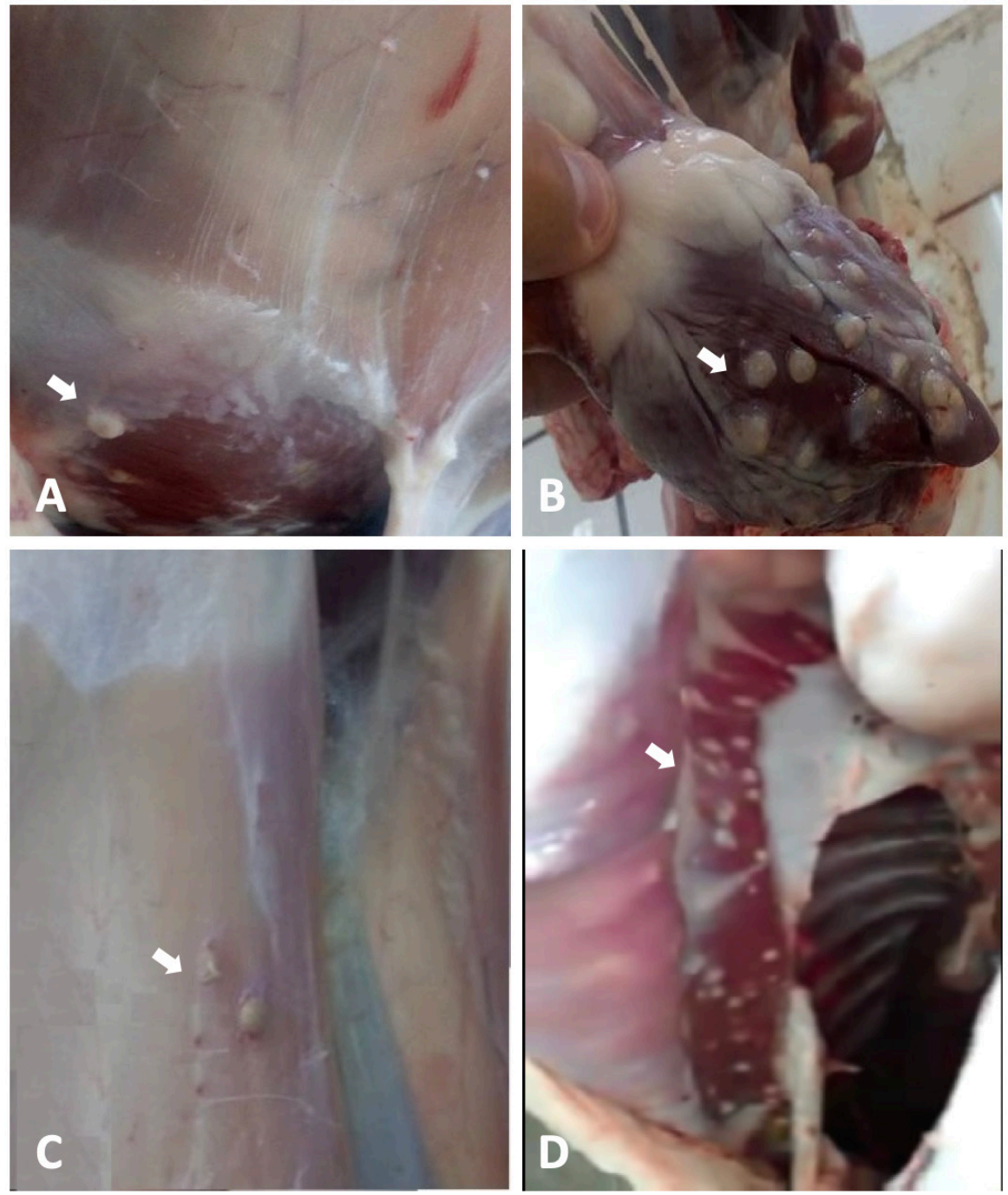

Figure 3. Different muscles of slaughtered sheep infected with Cysticercus ovis cyst; (A) C. ovis on costal muscles; (B) C. ovis on cardiac muscles; (C) C. ovis on abdominal muscles and (D) C. ovis on diaphragmatic Muscles.

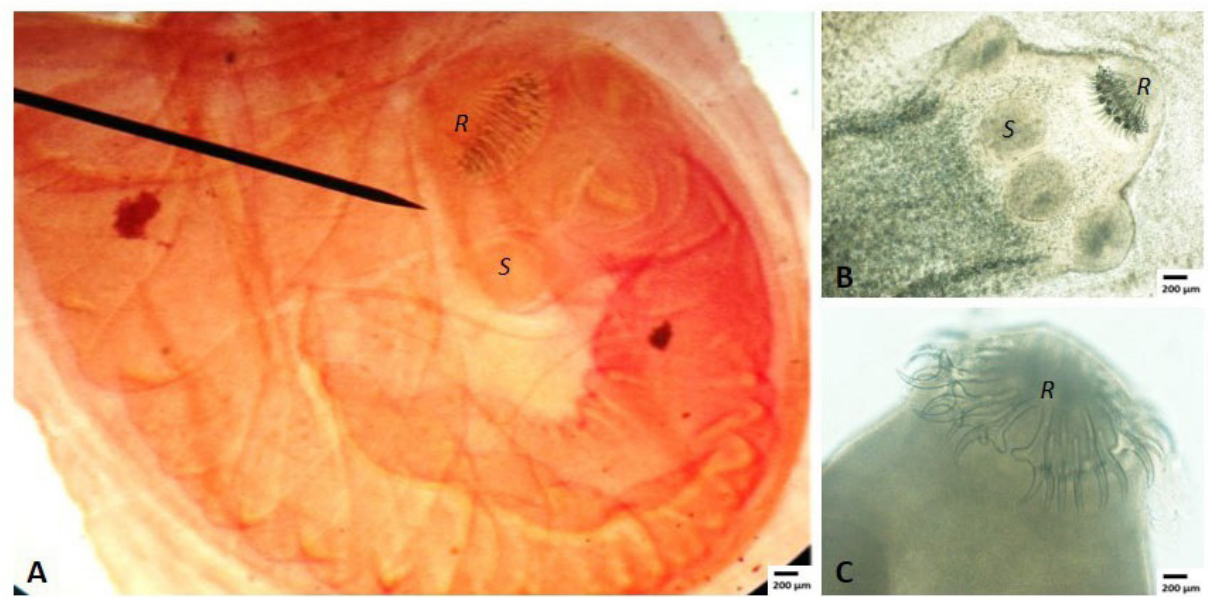

Figure 4. Microscopic examination Cysticercus ovis cyst, (A) invaginated protoscolex (stained by carmine), (B) unstained evaginated protoscolex with rostellum and 4 suckers, (C) rostellum with taeniid (X 100). (R) is for Rostellum and (S) is for Sucker. 
it shared $75 \%-91.3 \%$ identity with this gene in other Taenia species including T. solium, T. serialis, T. saginata, T. multiceps, T. hydatigena, $T$. crocutae, $T$. twittchelli, $T$. asiatica, $T$. regis and T. madoquae.

\section{Discussion}

The overall prevalence of $C$. ovis in this study was $2.02 \%$, which agreed with the previous studies conducted on $C$. ovis among sheep, with a prevalence of $1.9 \%$ in Upper Egypt (DYAB et al., 2017), 2.3\% in Saudi Arabia (AL-QUREISHY, 2008) and 1.3\% in Iran (HASHEMNIA et al., 2016), although this was relatively higher than those recorded in Qena, Upper Egypt (0.35\%) (ALI, 2013) and in Iran (0.1\%) (ORYAN et al., 2012).

However, the obtained prevalence is lower than those reported in sheep of Cairo, Egypt (5.7\%) (ABEDL-MAOGOOD, 2005), in sheep of Western Australia (20.5\%) (WHITE, 1976), in goats of eastern Ethiopia (22\%) (SISSAY et al., 2008), in sheep of China (58.9\%) (Shi et al., 2016), in sheep of Canada (48\%) (DEWOLF et al., 2012) and in sheep of south-west England (7\%) (EICHENBERGER et al., 2011).

As observed during doing the current study, several factors can be suggested to contribute the existence and continuity of infection with T. ovis in dogs and its metacestode $C$. ovis in sheep. Lost sheep roaming the streets and feeding on garbage which may be contaminated by stool from stray dogs can exposes sheep to many infective parasites eggs such as T. ovis. Many sheep are slaughtered daily outside the inspection facilities in order to avoid inspection charges and carcass condemnation, which increases the risk of the infection transmission cycle between dogs and sheep. Moreover, in the rural and urban areas, guardian dogs that are living with the sheep flocks during grazing to protect them from wild carnivores are also playing an important role in the transmission of dog-sheep tapeworms including sheep measles caused by T. ovis.

Therefore, preventing the sheep from being exposed to the tapeworm is essential and can be accomplished by deworming the farm or guardian dogs routinely, keeping the stray and wild carnivores away from the sheep grazing areas and hygienic disposal of both condemned carcasses and dead sheep. In addition, prevention and control of slaughter outside the meat inspection facilities by extending these facilities to rural and urban areas and supporting them with well-trained inspectors and veterinarians, as well as diagnostic tools, can further prevent exposure.

The infection rate of $C$. ovis was higher among males $(52.63 \%)$ than females (47.36\%), however without a significant difference $(P<0.01)$ and with no association between animal sex and the infection rate. These results agree with Senlik (2008) and Jayousi (2014) who found that the highest infection rates were observed in male animals (26\% and $2.7 \%$, respectively) compared to females (23.9\% and $2.15 \%$, respectively).

In contrast our results disagree with other studies that have been done in Egypt (ABU-ELWAFA \& AL-ARABY, 2008; DYAB et al., 2017; OMAR et al., 2016), where the infection rates were higher in ewes than rams. This may be due to the higher numbers of slaughtered younger rams in comparison to ewes, as the meat of rams is more favored for consumption by the public, while ewes are preferred and kept alive for longer times for breeding and giving birth.

For different age groups, the effect on infection rates was epidemiologically insignificant. Infection in adults above 4 years old was higher than in younger animals, however without significant differences $(P<0.01)$. This result is in accordance with the results of earlier studies done in Egypt (ABU-ELWAFA \& AL-ARABY, 2008; ALI, 2013; DYAB et al., 2017), where the infection rates of C. ovis were higher among older adult sheep than in young ones. This may be because of longer time of companionship with the guardian dogs during grazing in adults, while lambs are mostly kept in houses. In addition, the older (over 1-2 years old) and heavier sheep (mostly males) are more favorable for slaughter, and the older females that are finished breeding (mostly over 4 years old) are prepared for slaughter. For all these reasons, the older sheep aged over 4 years old represented a large proportion in the collected samples and subsequently were more highly infected.

As for $C$. ovis preferred site of infection in the examined muscles, there was a significant relationship between the location of the cyst and infection rates, with the highest proportion in cardiac muscles which reflects the tissue tropism of the parasite to the cardiac muscles. This may be due to the migration of the hexacanth embryo through the circulation system to the caudal vena cava, then eventually to the heart where the embryos settled in cardiac muscle, the first muscle of which they can live and encyst inside. The remaining number of circulating embryos will settle subsequently in diaphragmatic, costal and abdominal muscles. These results are in agreement with many previous studies worldwide (DYAB et al., 2017; GESSESE et al., 2015; HASHEMNIA et al., 2016; ZHENG, 2016).

Several earlier studies have been done concerning the molecular identification of T. ovis worldwide (DEWOLF et al., 2012; LAVIKAINEN et al., 2008, 2010; SHI et al., 2016). Adding to this, the present study investigated the molecular identity of T. ovis in sheep of Upper Egypt and identified the possible origin of the parasite isolate. The results revealed that this isolate is $99 \%$ similar to New Zealand isolates. However, it is impossible to determine the original source of the sheep in the country, and the infection might also be transmitted to the local sheep via imported sheep from other countries. Further phylogenetic analysis studies should be carried out in final and intermediate hosts at molecular levels.

\section{Conclusion}

The present study elucidates the prevalence of $C$. ovis infection in Egyptian slaughtered sheep at abattoirs. The main associated risk factors for sheep infection with $C$. ovis in the study areas were the age of the animals and the affected muscles (parasite tissue tropism).

C. ovis needs further epidemiological and molecular studies to allow for the country of Egypt to enhance effective planning for parasite prevention and control. Local animal health care authorities are asked to limit the infection among stray dogs by controlling illegal slaughter outside the abattoirs and hygienic disposal of abattoir offals, condemned organs and tissues. In addition to 
this, sheep should be kept in hygienic rearing systems away from contact with stray dogs or contaminated foods and garbage.

Obviously molecular diagnosis for $C$. ovis infection significantly helps to differentiate it from such other metacestode and its relation to other taeniid cestodes worldwide, which shows an absolutely different pathogenicity and requires different control programs.

\section{Acknowledgements}

The authors are grateful to the veterinarians of the abattoirs for their help in providing data and sample collection throughout the study.

\section{References}

Abedl-Maogood SZ. Studies on metacestode of sheep with reference to serodiagnosis of Coenurus cerebralis [tese]. Cairo: Faculty of Veterinary Medicine, Cairo University Egypt; 2005.

Abu-Elwafa S, Al-Araby M. Prevalence of tissue parasites among slaughtered animals in Dakahlia province, Mansoura. Med Vet J 2008; 10(1): 79-91.

Abuladze K, Skrjabin K. Essentials of cestodology. Taeniata of animals and humans and diseases caused by them. USA: IPST; 1964. Helminthological Inst. S.

Aidaros H. Global perspectives--the Middle East: Egypt. Rev Sci Tech 2005; 24(2): 589-596.

Ali AA. Studies on parasitic infestation in some slaughtered animals in upper Egypt [tese]. Assuit: Faculty of Veterinary Medicine, Assuit University Egypt; 2013.

Al-Qureishy S. Prevalence of cestode parasites in sheep slaughtered in Riyadh City, Saudi Arabia. J Egypt Soc Parasitol 2008; 38(1): 273-280. PMid:19143137.

Bowles J, McManus DP. Genetic characterization of the Asian Taenia, a newly described taeniid cestode of humans. Am J Trop Med Hyg 1994; 50(1):33-44. http://dx.doi.org/10.4269/ajtmh.1994.50.1.TM0500010033. PMid:7905720.

DeWolf B, Peregrine A, Jones-Bitton A, Jansen J, Menzies P. Taenia ovis infection and its control: a Canadian perspective. NZ Vet J 2014; 62(1): 1-7. http://dx.doi.org/10.1080/00480169.2013.832109. PMid:24053136.

DeWolf BD, Peregrine AS, Jones-Bitton A, Jansen JT, MacTavish J, Menzies PI. Distribution of, and risk factors associated with, sheep carcass condemnations due to Cysticercus ovis infection on Canadian sheep farms. Vet Parasitol 2012; 190(3-4): 434-441. http://dx.doi.org/10.1016/j. vetpar.2012.07.019. PMid:22877826.

Dyab AK, Marghany ME, Osman RA, Ahmed MA. Cysticercosis in Small Ruminants Slaughtered in Aswan Slaughterhouse, Egypt. Assiut Vet Med J2017; 63(155): 1-8. http://dx.doi.org/10.13140/RG.2.2.16740.88967.

Eichenberger R, Karvountzis S, Ziadinov I, Deplazes P. Severe Taenia ovis outbreak in a sheep flock in south-west England. Vet Rec 2011; 168(23): 619a. http://dx.doi.org/10.1136/vr.d887. PMid:21642295.

Fahmi SA. Studies on larval cestodes infecting sheep and cattle. Cairo, Egypt: Cairo University; 2014.

Gessese AT, Mulate B, Nazir S, Asmare A. Major metacestodes in small ruminants slaughtered at Dessie municipal abattoir, Eastern Ethiopia: prevalence, cyst viability, organ distribution and economic implications.
Comp Clin Pathol 2015; 24(3): 659-668. http://dx.doi.org/10.1007/ s00580-014-1964-0.

Hashemnia M, Shahbazi Y, Kish GF. Prevalence and pathological lesions of ovine cysticercosis in slaughtered sheep in western Iran. J Parasit Dis 2016; 40(4): 1575-1578. http://dx.doi.org/10.1007/s12639-015-07327. PMid:27876986.

Jayousi AAY. Prevalence and Molecular Characterization of Cysticercus tenuicollis Cysts in Sheep Slaughtered in Palestine [tese]. Nablus: An-najah National University; 2014.

Jia WZ, Yan HB, Guo AJ, Zhu XQ, Wang YC, Shi WG, et al. Complete mitochondrial genomes of Taenia multiceps, T. hydatigena and T. pisiformis: additional molecular markers for a tapeworm genus of human and animal health significance. BMC Genomics 2010; 11(1): 447. http://dx.doi. org/10.1186/1471-2164-11-447. PMid:20649981.

Kaufmann J. Parasitic infections of domestic animals: a diagnostic manual. Birkhäuser: Birkhäuser Basel; 2013.

Lavikainen A, Haukisalmi V, Lehtinen M, Henttonen H, Oksanen A, Meri S. A phylogeny of members of the family Taeniidae based on the mitochondrial cox 1 and nad1 gene data. Parasitology 2008; 135(12): $1457-$ 1467. http://dx.doi.org/10.1017/S003118200800499X. PMid:18937885.

Lavikainen A, Haukisalmi V, Lehtinen MJ, Laaksonen S, Holmström S, Isomursu M, et al. Mitochondrial DNA data reveal cryptic species within Taenia krabbei. Parasitol Int 2010; 59(2): 290-293. http://dx.doi. org/10.1016/j.parint.2010.03.003. PMid:20304093.

Nakao M, Lavikainen A, Iwaki T, Haukisalmi V, Konyaev S, Oku Y, et al. Molecular phylogeny of the genus Taenia (Cestoda: Taeniidae): proposals for the resurrection of Hydatigera Lamarck, 1816 and the creation of a new genus Versteria. Int J Parasitol 2013; 43(6): 427-437. http://dx.doi. org/10.1016/j.ijpara.2012.11.014. PMid:23428901.

Omar MAE, Elmajdoub LO, Al-Aboody MS, Elsify AM, Elkhtam AO, Hussien AA. Molecular characterization of Cysticercus tenuicollis of slaughtered livestock in Upper Egypt governorates. Asian Pac J Trop Biomed 2016; 6(8): 706-708. http://dx.doi.org/10.1016/j.apjtb.2016.06.009.

Oryan A, Goorgipour S, Moazeni M, Shirian S. Abattoir prevalence, organ distribution, public health and economic importance of major metacestodes in sheep, goats and cattle in Fars, southern Iran. Trop Biomed 2012; 29(3): 349-359. PMid:23018497.

Perry B, Randolph T. Improving the assessment of the economic impact of parasitic diseases and of their control in production animals. Vet Parasitol 1999; 84(3-4): 145-168. http://dx.doi.org/10.1016/S03044017(99)00040-0. PMid:10456413.

Senlik B. Influence of host breed, sex and age on the prevalence and intensity of Cysticercus tenuicollis in sheep. J Anim Vet Adv 2008; 7(5): 548-551.

Shi W, He W, Guo X, Liu Q, Gao S, Zhan F, et al. The first outbreak of Taenia ovis infection in China. Parasitol Int 2016; 65(5 Pt A): 422 423. http://dx.doi.org/10.1016/j.parint.2016.06.005. PMid:27276429.

Sissay MM, Uggla A, Waller PJ. Prevalence and seasonal incidence of larval and adult cestode infections of sheep and goats in eastern Ethiopia. Trop Anim Health Prod 2008; 40(6): 387-394. http://dx.doi.org/10.1007/ s11250-007-9096-z. PMid:18575964.

Soulsby EL, Mönnig H. Helminths, arthropods and protozoa of domesticated animals. 7th ed. Michigan: Bailliere Tindal \& Cassell; 1982. 
Sultan K, Desoukey A, Elsiefy M, Elbahy N. An abattoir study on the prevalence of some gastrointestinal helminths of sheep in Gharbia Governorate, Egypt. Glob Vet 2010; 5(2): 84-87.

Sultan K, Elmonir W, Hegazy Y. Gastrointestinal parasites of sheep in Kafrelsheikh governorate, Egypt: Prevalence, control and public health implications. Beni-SuefUniv J Basic ad Appl Sci 2016; 5(1): 79-84. https:// doi.org/10.1016/j.bjbas.2015.12.001.

Tamura K, Stecher G, Peterson D, Filipski A, Kumar S. MEGA6: molecular evolutionary genetics analysis version 6.0. Mol Biol Evol 2013; 30(12): 2725-2729. http://dx.doi.org/10.1093/molbev/mst197. PMid:24132122.
White JB. Incidence of Cysticercus ovis in sheep and lambs at Albany, Western Australia. Aust Vet J 1976; 52(3): 118-122. http://dx.doi. org/10.1111/j.1751-0813.1976.tb05442.x. PMid:985239.

World Organisation for Animal Health - OIE. WAHIS interface [online]. 2017 [cited 2018 Dec 18]. Available from: https://www.oie.int/wahis_2/ public/wahid.php/Countryinformation/Animalpopulation

Zheng Y. Taenia ovis: an emerging threat to the Chinese sheep industry? Parasit Vectors 2016; 9(1): 415. http://dx.doi.org/10.1186/s13071-0161700-5. PMid:27460570. 